\title{
Marketing Management Innovation from the Perspective of Project Management
}

\section{Gui Huihui}

Wuchang University of Technology, Wuhan, 430223

Keywords: Project Management, Marketing Management, Innovation

\begin{abstract}
With the development of economics, the management of marketing activities of enterprises faces new challenges. The traditional marketing activities cannot adapt to the requirements of knowledge-based economy. While new markets put forward higher performance standards for marketing activities. This paper first elaborates the necessity and possibility of marketing innovation in the current situation, then elaborates the innovation mode of marketing activities, and analyzes the problems and difficulties in the marketing activities based on project management. Finally, the corresponding solutions are proposed, hoping to promote the marketing activities.
\end{abstract}

\section{Introduction}

The marketing department is very important to an enterprise. The marketing department can not only help the enterprise open the market and realize the economic benefits, but also timely feedback the market information and help the enterprise to adjust the marketing and product strategy. However, the traditional marketing model can't adapt to the current market environment, also can't help business development. The concept of project management has gradually been introduced into marketing management. Enterprises realize that project management can rapidly integrate enterprise resources and help enterprises improve their competitiveness. However, marketing activities based on project management can adapt to new forms and improve marketing management performance, to help business get more advantages in the market, and promote the rapid development of enterprises.

\section{Necessity and importance of project management based on the marketing management innovation}

\subsection{Problems of traditional marketing management}

Analysis of the traditional management of marketing activities, the problems of modern business marketing are mainly concentrated in the marketing organization management structure, strategic marketing arrangements, marketing, cost management and marketing management methods in four areas. As for the organizational structure of the enterprise marketing, the prominent problems are inflexible, too many branches of marketing, inter-departmental collaboration difficult, each department is only responsible for their own work, in the face of cooperation requests from other departments are often push the buck can hide to hide. It is difficult to carry out a comprehensive marketing campaign which is inefficient and has a low working effectiveness. However, the marketing strategy of the enterprise lacks systematization in the arrangement, and often only focuses on the immediate, but cannot achieve gradual and gradual progress. The link of each link of the marketing is not in place and cannot co-ordinate the time and capital. As a result, the overall marketing management of the enterprise appears cluttered, spent a lot of time and money, but did not achieve the desired marketing effect. Some companies in the management of marketing costs, no rules, cost accounting cannot be fine, let alone cost control. Marketing management methods and methods are too old, can't be updated in time, the business for the past marketing activities do not establish a sound file, can’t sum up experience from past projects, improve marketing methods. 


\subsection{The development tendency of marketing activities management based on project development}

With the development of market economy and constant changes of consumer spending habits, the current market presents unprecedented new features such as quietly changing the position of buyers and sellers and the need of consumers no longer limited to a simple single, but also towards a higher level, in the direction of individuality, diversification and complexity. There are also major changes in consumer access to information, manifested in multiple channels and multiple forms. The traditional marketing is generally the first to conduct market research, and then invest in marketing, but in the face of major changes in the market environment, in the face of more uncertainty and risk, companies gradually marketing management project Instead of simply repeating the marketing campaign, we should give full play to the characteristics of project-oriented projects, such as high purpose, high efficiency and adaptability to respond to the ever-changing market environment.

\subsection{The meaning of the project management}

Since the 1980s, some enterprises have gradually introduced the modular ideas and methods in the software factory into the management of enterprises in order to strengthen management and improve the enterprise management system. In particular, some large enterprises such as Citibank, IBM Corporation and so on, through such project management successfully improve the business management system, making business management performance soared, and thus promote the rapid development of enterprises. The so-called project management is through the deployment of multiple tasks in the company and steps to decompose, and then re-combination of the management part of the reorganization so that it can work more efficient and faster, and ultimately achieve a corporate strategic goal management mode. Project management is a way to manage the process and procedure by decomposing and combining multiple jobs, which has a significant effect on improving the management efficiency and effectiveness of an enterprise. At the same time, it can reduce the management cost and risk of the enterprise and help the enterprise better management purposes, to help enterprises achieve greater economic efficiency.

\subsection{The level of project management}

Project management can be divided into three levels, the first level is the portfolio management of enterprise project investment, the second level is to manage the project team, the third level is the project management. Project management theory through continuous development and improvement, derived from a variety of related theories, and business management practice found that project management is the most in line with the modern enterprise management of a project management level. Project management is the overall arrangements for all the work of the enterprise, focus on the development plan, the tasks involved in the co-ordination, to promote more efficient and faster work to complete and control the management approach. Project management is a kind of systematic management activities with definite purpose. Through the systematic integration of the work of the whole company, it fully allocates employees of all departments and strengthens the cooperation among departments and departments, employees and employees to improve the overall work efficiency of the enterprises, and then improve the competitiveness of enterprises, to achieve corporate marketing objectives.

\section{Marketing management based on the project management perspective}

\subsection{The meaning of marketing management model based on project management}

Marketing management on the basis of project management refers to a comprehensive analysis of the overall marketing plan of an enterprise, integrating marketing activities through project management and achieving project management to a certain extent, mainly through marketing project management and marketing project team management. The so-called corporate marketing project generally refers to pre-market market research, or new product marketing activities, or 
corporate products related to public relations activities, these marketing activities require the relevant project management. Marketing Project Management is the integration of a number of related businesses marketing activities, into a unified management of the project group, if through the management of the project, so that each marketing activity not only achieved the desired results, and management of process costs lower, better, then such a marketing management is a successful project management based marketing management.

\subsection{The features of marketing management model based on project management}

The first notable feature of the marketing management model based on the perspective of project management is that the marketing activities of the enterprises are related to each other. Instead of merely focusing on the success of one marketing campaign, each marketing campaign and the overall marketing of the enterprise planning together, a single marketing project for the realization of the overall marketing objectives and services, and ultimately achieve the overall strategic goal of the enterprise. The second notable feature is that all the marketing activities of an enterprise are systematic. The marketing activities and plans are implemented step by step and step by step. When each stage of the marketing goal of the enterprise is realized, the overall marketing goal of the enterprise naturally reached, then a systematic marketing management. The third significant feature is market-oriented, fully analyzing the specific needs of consumers, focusing on the wishes of various types of consumers, according to these collective needs targeted to develop business sales goals, develop business marketing plan program. The marketing management mode based on the perspective of project management fully embodies the cooperation spirit of the enterprise. The target management requires efficient cooperation among all staff in each department and finally achieves the marketing strategic target of the enterprise by unifying the team's strength.

\subsection{The structure of marketing management model based on project management}

There are mainly two kinds of management modes of marketing activities on the basis of project management, one is the management of a single marketing project and the other is the management of a project group composed of multiple marketing activities. According to the project management theory, the management process is divided into the start-up phase, planning phase, the specific implementation phase and the final phase. The methods used at different stages of marketing activities are also different. For example, in the planning stage of marketing activities, market research and analysis are mainly used to analyze the market and consumers to determine the objectives of marketing activities and the marketing methods, and the effect of predicting marketing activities. In the implementation phase, we must supervise and control the completion of the marketing plan and plan formulated so as to ensure the expected marketing effect. Finally, we conclude and conclude the project so as to achieve the success of the marketing project management.

\subsection{Marketing Project Group}

Marketing project group is to integrate multiple marketing activities of the enterprise management, marketing management of the project group not only on the project itself, but also focus on the overall marketing plan and strategy of enterprises to grasp the follow-up effect of marketing activities and continuity, to ensure the realization of the ultimate goal of marketing. Marketing project management team grasp the strategic direction of the entire marketing activities on the one hand, on the one hand, each of the marketing activities to monitor and control, timely detection of problems, solve problems, promptly correct the wrong direction, and in the management of the accumulation of marketing experience and marketing methods of innovation, the ultimate realization of the successful management of the marketing project group. In the process of marketing project management team should pay attention to coordinated management, phased assessment of the effectiveness of marketing activities in order to promptly adjust the marketing program to achieve effective control of project management. 


\subsection{Marketing project management}

The management of marketing project is to manage single marketing activities of the enterprise, supervise and control the pre-period, mid-term and post-marketing activities of the marketing activities, achieve accurate analysis in the planning stage, plan accurately and achieve effect control in the implementation stage, assessment and assessment, timely detection of problems, timely improvement programs, and provide some help at the appropriate time, after a timely summary of experiences and lessons learned, making the entire marketing project successfully completed.

\section{The main obstacle to marketing management model based on project management}

As for as the current status of Chinese enterprises, it is different to carry out marketing activities innovation. First, the corporate decision-makers pay insufficient attention. Many corporate executives do not know enough about the new market environment, leading them to know little about the project management that needs to be introduced under the new form. The lack of awareness of project management makes the project management perspective cannot be talked about under the circumstance of marketing management innovation. Second, corporate project management knowledge is seriously lagging behind. In today's rapidly changing market, knowledge is rapidly changing. Project management only changes with changes in the market. Although many enterprises attach importance to project management, they lack market sensitivity and cannot update project management knowledge in a timely manner. Third, lack of talent, the development of enterprises rely on the talent, the implementation of project management needs the participation of talented people. Many enterprises attach importance to the project management, but suffer from the lack of talent, marketing project management work cannot be carried out smoothly, especially proficient in project management and marketing management of dual talents, it is rare.

\section{The marketing management activities for innovation in response to the problem}

In view of the problems in the marketing management innovation proposed in this paper, the following improvement strategies are proposed. First of all, to improve business awareness of project management, in particular, to enhance business executives pay attention to project management, through internal training or invited experts and scholars for business management training in project management related knowledge so that they understand the current market environment, the necessity and importance of project management. Second, the establishment and improvement of enterprise information management system, timely update project management information, starting from the enterprise strategy formulation, will be the goal of project allocation and management. Finally, increase the training of enterprise project management applications, especially the training of relevant management personnel. Enterprises should be conscious of the project management personnel training, training of relevant knowledge, and give the appropriate project management practice opportunities for them to combine theory and practice, and ultimately become the business needs of personnel. Enterprises should also pay attention to the training of project management knowledge of the bottom managers and improve the cognition of the bottom managers, which will be conducive to the smooth implementation of project management. For project management personnel, enterprises in addition to internal training, but also by way of recruitment directly into the business needs of personnel.

\section{Conclusions}

The management of marketing activities under the perspective of project management is the requirement of market development and the future direction of marketing. This article elaborates the connotation of project management, and illustrates the necessity and importance of the management of marketing activities under project management in the current era of knowledge economy. Through the analysis of the current marketing management mode, let us see the necessity of marketing management innovation from the perspective of project management. Although there are 
many difficulties encountered in the process of marketing management innovation, such as neglect of management and talent shortage, Put forward some opinions and suggestions, hoping to improve the existing business marketing management. To improve the enterprise awareness of project management, increase the training of project management personnel in order to enhance the marketing management capabilities of enterprises in order to enhance their own competitiveness in order to help businesses get greater benefits.

\section{References}

[1] Xia Weili, Jiang Jiao. Project management in the organization market research application [J]. Journal of Northwestern Polytechnical University (Social Science Edition), 2002, 22 (1): 21 - 24.

[2] Qiu Shihong. On Marketing Management Innovation Based on the Perspective of Project Management [J]. Science and Technology, 2015 (35): 94-94.

[3] Ge Baoshan, Jia Baoqiang, Zhang Hong et al. Marketing management innovation based on project management perspective [J]. Management Modernization, 2015 (3): 23-25.

[4] Ge Baoshan. Research on enterprise comprehensive project management based on environmental information [J] .Journal of Information Science, 2013, 21 (8): 308-310. 